\section{Scientific journal}

PHYSICAL AND MATHEMATICAL EDUCATION

Has been issued since 2013.

Науковий журнал

ФІЗИКО-МАТЕМАТИЧНА ОСВІТА

Видається з 2013.
ISSN 2413-158X (online)

ISSN 2413-1571 (print)

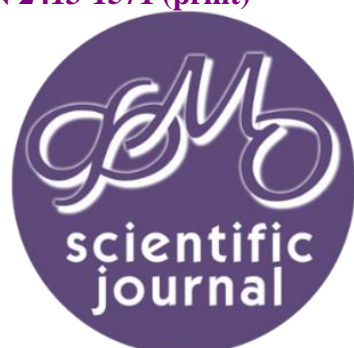

Коваленко В.В. Застосування хмаро орієнтованих сервісів відкритої науки для професійного розвитку вчителів. Фізико-математична освіта, 2021. Випуск 5(31). С. 45-53.

Kovalenko V. Application of cloud oriented open science services for professional development of teachers. Physical and Mathematical Education, 2021. Issue 5(31). P. 45-53.

DOI 10.31110/2413-1571-2021-031-5-007

УдК 378.046.4:009

В.В. Коваленко

Інститут інформаційних технологій і засобів навчання НАПН України, Україна vako88@ukr.net

https://orcid.org/000-0002-4681-5606

\title{
ЗАСТОСУВАННЯ ХМАРО ОРІЕНТОВАНИХ СЕРВІСІВ ВІДКРИТОЇ НАУКИ ДЛЯ ПРОФЕСІЙНОГО РОЗВИТКУ ВЧИТЕЛІВ
}

\section{АНОТАЦІЯ}

У статті проаналізовано особливості застосування хмаро орієнтованих сервісів відкритої науки для професійного розвитку вчителів. Розглянуто важливість застосування принципів та інструментів відкритої освіти і науки для підвищення кваліфікації педагогічних працівників, особливо в умовах глобальної цифровізації. Підготовлено рекомендації щодо напрямів застосування хмаро орієнтованих сервісів відкритої науки педагогічними працівниками: для самоосвіти і саморозвитку педагогічних працівників; для підготовки нових навчальних матеріалів і дослідницьких завдань для учнів; для роботи з обдарованими дітьми і добір для них додаткових навчальних і дослідницьких завдань; для демонстраціі і візуалізації різноманітних природніх і експериментальних процесів під час освітнього процесу; для перевірки на плагіат учнівських дослідницьких проектів.

Формулювання проблеми. Для даного дослідження важливим $\epsilon$ аналіз особливостей застосування хмаро орієнтованих сервісів відкритої науки для професійного розвитку вчителів. Тому, проаналізуємо процес підготовки майбутніх вчителів, приклади застосування хмаро орієнтованих сервісів відкритої науки у практиці роботи з3со та підвищення кваліфікації педагогічних працівників із застосуванням сервісів відкритої науки.

матеріали і методи. Для досягнення мети дослідження було використано теоретичні методи: аналіз, систематизація, узагальнення наукових джерел, аналіз наукових публікацій вітчизняних і закордонних вчених. Дослідження виконано в межах проєкту “Хмаро орієнтовані системи відкритої науки у навчанні і професійному розвитку вчителів» (реєстраційний номер 2020.02/0310), що реалізується за рахунок грантової підтримки Національного фонду досліджень України.

Результати. У дослідженні проаналізовано особливості застосування хмаро орієнтованих сервісів відкритої науки для професійного розвитку вчителів. Зроблено висновок щодо важливості застосування принципів та інструментів відкритої освіти і науки для підвищення кваліфікації педагогічних працівників, особливо в умовах глобальної цифровізаиії. Підготовлено рекомендації щодо напрямів застосування хмаро орієнтованих сервісів відкритої науки педагогічними працівниками: для самоосвіти і саморозвитку педагогічних працівників; для підготовки нових навчальних матеріалів і дослідницьких завдань для учнів; для роботи з обдарованими дітьми і добір для них додаткових навчальних і дослідницьких завдань; для демонстрації і візуалізації різноманітних природніх $і$ експериментальних процесів під час освітнього процесу; для перевірки на плагіат учнівських дослідницьких проектів.

Висновки. Проведене дослідження дає підстави зробити висновок, щодо важливості застосування приниипів та інструментів відкритої освіти і науки для підвищення кваліфікації педагогічних працівників, адже в умовах глобальної цифровізації та карантинних обмежень викликаних хворобою COVID-19 саме на них покладена важливе суспільне завдання - не переривати освітній процес у закладах загальної середньої освіти, адже діти мають отримувати знання і здобувати освіту не зважаючи на суспільні обставини.

ключОвІ СлОвА: відкрита наука, інструменти відкритої науки, цифрові технології, вчителі, професійний розвиток.

\section{ВСТУП}

Постановка проблеми. В сучасних умовах розвитку і поширенню парадигми відкритої науки сприяло розповсюдження цифрових технологій, що зумовило необхідність оновлення підходів до реалізації досліджень загалом та осучаснення підходів і змісту освіти зокрема. Цифрова трансформація характеризується інноваційністю, доступністю, безперервністю процесів, адаптивністю до нових задач, розвитком кадрового потенціалу та нових компетенцій, конкурентоспроможністю, підвищенням ефективності та ін. (Мар'єнко\&Носенко\&Сухіх, 2020).

(C) В.В. Коваленко, 2021. 
3 метою реалізації принципів відкритої науки у Європі було створено проект «Європейська хмара відкритої науки» (EOSC). EOSC $€$ віртуальним середовищем з відкритими сервісами для управління, зберігання, аналізу та повторного використання дослідницьких даних, об'єднує в собі існуючі наукові інфраструктури держав-членів ЄС. У Дорожній карті для впровадження EOSC описано шість напрямків реалізації «Європейської хмари відкритої науки» з конкретними етапами та пов'язаними з ними прикладами (EOSC Portal).

У дослідженні (Мар'єнко, 2020) зазначено, що хмаро орієнтовані системи відкритої науки надають дослідницьким спільнотам високопродуктивну хмарну інфраструктуру для зберігання наукоємних даних. Впровадження хмаро орієнтованих систем відкритої науки передбачає забезпечення як високої продуктивності, так і простоту використання не лише науковими спільнотами, але й у навчанні та професійному розвитку вчителів. Результатом $€$ низка проєктів, що використовують хмаро орієнтовані системи відкритої науки у природничих, біологічних науках та гуманітарних. Посилена потреба у розширенні інфраструктури хмаро орієнтованих систем і сервісів, що надаються для задоволення зростаючих потреб у даних наукових досліджень. Наразі стає можливим впровадження хмаро орієнтованих систем відкритої науки базуючись на нових технологіях, проведених уроків та нових дослідницьких проєктів.

Також принципи відкритої науки сприятимуть ефективнішому подоланню розрив між дослідниками та вчителями. В основі розуміння відкритої науки закладено концепцію того, що дослідження повинно бути відтворюваним і прозорим, крім того вони мають довгострокову цінність завдяки ефективному збереженню та обміну даними. Використання принципів відкритої науки може бути корисним для навчання та професійного розвитку вчителів, для формування хмаро орієнтованих систем відкритої науки. Впровадження хмаро орієнтованих систем відкритої науки у процес навчання і професійного розвитку вчителів призведе до підвищення рівня організації дистанційного та змішаного навчання в школах (Мар'єнко, 2021).

Погоджуємося із зазначеним у роботі (Мар'єнко, 2021) про те, що у 2020-2021рр. в зв'язку з запровадженням карантинних заходів спричинених хворобою COVID-19 більшості шкіл України було переведено на дистанційну форму навчання. Незважаючи на активне застосування вчителями хмаро орієнтованих систем існують певні проблеми в організації навчання та професійного розвитку вчителів. Однією з основних проблем постає відсутність методик використання хмарних сервісів, що не є локалізованими, але безкоштовними для застосування для наукових та навчальних цілей. Використання хмаро орієнтованих систем відкритої науки дозволить зробити навчальний процес більш науковим та академічним, призведе до вирішення окремих проблем академічної доброчесності серед вчителів та учнів (Мар'єнко, 2021). Тому вважаємо, що потребують подальшого дослідження різні аспекти застосування хмаро орієнтованих сервісів відкритої науки для професійного розвитку вчителів.

У публікації (Мар'єнко\&Шишкіна, 2020) представлено опитування освітян на тему: «Використання сервісів відкритої науки для постановки і дослідження стану наукової проблеми». Результати проведено опитування показали, що більшість респондентів в першу чергу цікавляться матеріалами своїх колег з престижних фахових журналів. Лише четверта частина респондентів взагалі знає, що таке відкрита наука. А це в свою чергу, також, підтверджує актуальність та доцільність нашого дослідження, щодо особливості застосування хмаро орієнтованих сервісів відкритої науки для професійного розвитку вчителів.

Аналіз актуальних досліджень. Про особливості впровадження принципів відкритої освіти і відкритої науки описано у публікаціях: Бикова В.Ю., Лещенко М.П., Олійника В.В., Яцишин А.В. та ін. Різні аспекти застосування інструментів відкритої науки розглянуто у дослідженнях: Вакалюк Т.А., Василенко А.Ю., Литвинової С.Г., Мар'єнко М.В., Носенко Ю.Г., Шишкіної М.П. та у дослідженнях зарубіжних вчених. Наразі в Україні організовують різні заходи щодо запровадження хмарних технологій відкритої науки в навчальний процес та обміну досвідом кращими освітніми практиками. Саме цій тематиці присвячений міжнародний семінар «Хмарні технології в освіті» (Cloud Technologies in Education, CTE), що проводиться щорічно з 2012 р. (https://cte.ccjournals.eu/cte2020/).

Мета статті: проаналізувати особливості застосування хмаро орієнтованих сервісів відкритої науки для професійного розвитку вчителів.

\section{МЕТОДИ ДОСЛІДЖЕННЯ}

Для досягнення мети дослідження було використано теоретичні методи: аналіз, систематизація, узагальнення наукових джерел, аналіз наукових публікацій вітчизняних і закордонних вчених. Дослідження виконано в межах проєкту «Хмаро орієнтовані системи відкритої науки у навчанні і професійному розвитку вчителів» (реєстраційний номер 2020.02/0310), що реалізується за рахунок грантової підтримки Національного фонду досліджень України.

\section{РЕЗУЛЬТАТИ ДОСЛІДЖЕННЯ}

Європейська комісія розпочала проект «Європейська хмарна ініціатива для побудови конкурентоспроможної економіки та знань у Європі» (EOSC) для підтримки відкритої науки. Завдяки даному проекту дослідники 3 різних європейських країн можуть опрацьовувати величезні обсяги наукових даних та ділитися своїми результатами, одночасно покращуючи доступ до нових наукових результатів, даних та інновації (European Commission / Shaping Europe's digital future. Open Science). У документі «Європейська хмара відкритої науки: нова парадигма для інновацій та технологій» описано EOSC як надійну цифрову платформу для наукової громади, що забезпечує надання безшовного доступу до даних та сумісних послуг, які стосуються всього цілу отримання даних з наукового дослідження (збір, управління, зберігання, аналіз та повторне використання даних).

Також, існує проєкт «Послуги для Європейської хмари відкритої науки» (EOSC-hub). Цей проект об'єднує багатьох постачальників послуг і утворює єдину контактну точку для європейських дослідників - це означає широкий доступ до послуг, програмного забезпечення для досліджень та розширення співпраці. 3 EOSC-hub тісно пов'язані ініціативи: OpenAIREAdvance, GEANT 4.2, elnfraCentral, RDA Europe 4.0 та EOSCpilot з метою забезпечення послугами дослідницькі спільноти по всій Європі. 
В документі «Відкриті інновації, Відкрита наука, Відкритість до світу - візія для Європи» описано перспективи роботи до 2030. Вказано, що відкрита наука стала реальністю і пропонує цілий ряд нових, необмежених можливостей для досліджень та відкриттів у всьому світі. Має бути забезпечений безкоштовний доступ до всіх наукових даних, що фінансуються державою. Парадигма Відкритої науки (Shaping Europe's digital future. Open Science) ґрунтується на ідеї трансформації науки за допомогою цифрових технологій, щоб зробити дослідження глобальним, відкритим, спільним, творчим та наближеними до суспільних потреб.

У дослідженні Василенко А.Ю. (Василенко, 2019) вказано, що однією з тенденцій розвитку правил міжнародної наукової співпраці в межах Європейського дослідницького простору $є$ застосування політики відкритої науки, зокрема відкритого доступу до наукових даних, що може розглядатися як симбіоз наукової та, частково, інформаційної політик. На практиці політику відкритої науки, з урахуванням сучасного етапу розвитку людства, найбільш ефективно можна реалізувати за допомогою окремого різновиду цифрових інфраструктур - е-інфраструктур. Впровадження політики відкритої науки на національному рівні в окремих державах має свої характерні риси. На прикладі Франції проаналізовано застосування парадигми відкритої науки на державному рівні. Описано можливе вдосконалення роботи органів державної влади, зокрема у сфері моніторингу реалізації парадигми відкритої науки. Показано роль е-інфраструктур, зокрема репозитаріїв наукових даних для застосування парадигми відкритої науки. Потребують подальшого аналізу підходи для подальшого використання міжнародного досвіду під час процесу формування національної політики відкритої науки в Україні (Василенко, 2019).

У 2017 р. комісією при МОН України було підготовлено дорожню карту інтеграції України до Європейського дослідницького простору (ERA-UA), 5-й пріоритет даного документа містить підрозділ «Відкрита наука і цифрові інновації». Також, розроблено документи «Цифрова аджента України - 2020» та «Концепція цифрової економіки та суспільства» (2018р.). І створено Міністерство цифрової трансформації України.

Для нашого дослідження важливим $€$ аналіз особливостей застосування хмаро орієнтованих сервісів відкритої науки для професійного розвитку вчителів. Тому, проаналізуємо процес підготовки майбутніх вчителів, приклади застосування хмаро орієнтованих сервісів відкритої науки у практиці роботи 33СО та підвищення кваліфікації педагогічних працівників із застосуванням сервісів відкритої науки.

Академік Биков В.Ю. у публікації (Биков, 2019 р.) розглядає сучасні тенденції розвитку інформаційного суспільства та проблеми впровадження цифрових технологій у вітчизняній освіті і науці; обґрунтовує пріоритети, технологічні принципи побудови інформаційно-освітнього середовища; визначає пріоритетні заходи для цифрової трансформації суспільства, а саме: впровадження на державному рівні процедур забезпечення необхідних рівнів досконалості електронних освітніх ресурсів; розроблення стандартів цифрових компетентностей суб'єктів освітнього процесу; розроблення та впровадження програми підвищення обізнаності громадян з питань кібербезпеки; створення технологічної інфраструктури закладів освіти на основі хмарних технологій та ін.

У роботі (Лупаренко\&Мар'єнко\&Носенко\&Сухіх\&Шишкіна, 2020) описано найбільш доцільні шляхи застосування компонентів «Європейської хмари відкритої науки» в освітньому процесі: гнучкість добору окремих їі інструментів $€$ досить зручною властивістю для організації навчального процесу як установи, так і окремих ї̈ структурних підрозділів; можливість використання EOSC в рамках окремих предметів чи навчальних дисциплін з їх подальшою інтеграцією та встановленням міжпредметних (міждисциплінарних) зв'язків; одночасне використання закладами освіти та науковими установами спільного набору сервісів задля співпраці (колаборації).

Шишкіна М.П. у публікації (Шишкіна, 2020) розглядає особливості формування віртуальних систем відкритої науки у закладах вищої освіти, що є суттєвою передумовою підготовки IKT-компетентних фахівців, здатних до активного, науково обгрунтованого застосування сучасних IKT у своїй професійній діяльності. Встановлено, що завдяки залученню в освітній процес закладів освіти засобів і сервісів науково-освітніх хмаро орієнтованих платформ, вдається досягти позитивних змін у здійсненні навчальної і наукової діяльності, поліпшенні їі якісних і кількісних показників, застосуванні нових форм і моделей іï організації, що позитивно впливає як на результати навчання, так і на розвиток наукових досліджень, поліпшення рівня їх організації, підвищення ефективності. Узагальнено досвід використання відкритих хмаро орієнтованих систем відкритої науки для спільної роботи; підтримування комунікації; адаптивного управління контентом; створення і використання електронних освітніх ресурсів та ін.

У колективному дослідженні (Шишкіна\&Попель, 2019) описано перспективи та сучасні європейські тенденції використання хмарних сервісів у системах відкритої науки; визначено можливості застосування хмарного сервісу Оffice 365 для експериментальної діяльності; представлено досвід впровадження окремих сервісів хмаро орієнтованого середовища у роботі наукової установи. Застосування хмарних сервісів сприяє побудові більш зручних, масштабованих систем організації доступу до електронних ресурсів для освітніх цілей і проведення наукових досліджень, покращуються умови для колективної роботи з програмними додатками зі зняттям географічних і часових обмежень, таким чином відбувається реалізація принципів відкритої науки та освіти.

Рябова 3.В. та Єльникова Г.В. умовно розділяють виклики, що наразі спонукають до стрімкого розвитку системи освіти та ії цифровізації, на зовнішні та внутрішні. Зовнішні вміщують в себе: 1) глобальний перехід освіти в оnline формат та модернізацію стратегічних цілей освіти в умовах цифровізації; 2) розбудова системи якості освіти як внутрішньої, так і зовнішньої й необхідність ї̈ цифрового забезпечення. Окреслене передбачає розроблення й опанування новими цифровими технологіями організації освітнього процесу, що й визначає сутність пролонгованого професійного зростання фахівця. Отже, в сучасних умовах провідним попитом у системі підвищення кваліфікації фахівців є розвиток гнучких навичок «Soft skills», які забезпечують високу продуктивність та результативність професійної діяльності (Рябова\&Єльникова, 2020).

У дослідженні (Рябова\&Єльникова, 2020) уточнено структуру професійної компетентності педагогів: спроможність особистості педагога до ефективної педагогічної діяльності з використанням цифрових сервісів; цифрові навички (використання Zoom, BigBlueButton (Open Source Web Conferencing), Google Meet тощо для організацій освітнього процесу й поширення інформації про навчальний контент у режимі реального часу); навички успішності професійної діяльності на основі проектного типу мислення як в реальному, так і в цифровому просторі. Вчені підкреслюють, що провідною навичкою 
стає опитування здобувачів освіти із застосуванням різних Інтернет-конструкторів для складання тестів перевірки навчального контенту та зворотного зв'язку.

Окрім активного обговорення та пасивної участі у різних наукових заходах (конференціях, вебінарах, семінарах тренінгах, майстер-класах) вчитель може бути ініціатором власних веб-заходів, організаторами яких можуть бути декілька вчителів, метою яких $€$ обмін накопиченим педагогічним досвідом та обговорення ключових тенденцій розвитку, досягнень та відкриттів педагогічної науки та практики. «Модель сучасного вчителя передбачає готовність до застосування нових педагогічних ідей, здатність безперервно навчатися та розвиватися, бути у постійному творчому пошуку та самовдосконалюватись». А забезпечити цю потребу може прогресивний та ефективний інструмент самоосвіти - ІКТ, що дозволяють зекономити час, є зручними для використання (Крива\&Пилипець, 2018).

Погоджуємося із зазначеним у роботі (Мар'єнко, 2021), про те, що «Впровадження принципів відкритої науки - це великий потенціал для прискорення як внутрішньо академічних, так і зовнішніх суспільних процесів навчання та створення нових знань, пришвидшення дослідницьких та інноваційних процесів для пошуку рішень для досягнення цілей сталого розвитку та головних викликів суспільства, а також вдосконалення процесу навчання і професійного розвитку вчителів. Відкрита інноваційна практика, що базується на використанні відкритих наукових результатів для впровадження інновацій у сфері освіти за межами закладів освіти». Також, у публікації [17] описано загальні принципи формування хмаро орієнтованих систем, а саме: індивідуалізації, варіативності, інтерактивності, інтеграції та надійності. Специфічними підходами до формування хмаро орієнтованих систем відкритої науки $€$ такі: часовий, інтеграційний, науковий, особистісно-орієнтований та проектувальний.

Мар'єнко М.В. у власному дослідженні зазначає, що «існує взаємозв'язок між відкритою наукою та відкритою освітою, що цілі та принципи відкритої науки можна впровадити в закладах вищої освіти». Також, дослідниця вказує на те, що хмаро орієнтовані системи відкритої науки майже не використовуються в закладах вищої освіти та на курсах підвищення кваліфікації вчителів. Тобто існують проблеми з використання хмаро орієнтованих систем відкритої науки через недостатню їх розробленість. Методика використання хмаро орієнтованих систем відкритої науки у процесі навчання і професійного розвитку вчителів має включати такі засоби навчання, щоб охопити різні потреби вчителів залежно від форми та навчальних предметів. Методика використання хмаро орієнтованих систем відкритої науки у процесі навчання майбутніх вчителів містить наступні компоненти: цільовий, змістовий, технологічний та результативний. Використання вчителями хмаро орієнтованих систем відкритої науки в рамках шкільних предметів сприяє урізноманітненню освітнього процесу та призведе до підвищення його науковості (Мар'єнко, 2021).

Литвиновою С.Г. у публікації (Литвинова, 2021) досліджено проблему застосування сервісів хмаро орієнтованих систем для професійного розвитку вчителів ліцеїв, як нового типу закладу освіти. «Специфіка ліцеїв, зокрема природничоматематичних, фізико-математичних, медичних, хіміко-технологічних та ін. потребує додаткових сервісів для демонстрації процесів живої та неживої природи. Для вирішення цієї проблеми вчителі ліцеїв можуть використовувати комп'ютерне моделювання та сервіси хмари відкритої науки». До прикладу, надання вчителям доступ до хмаро орієнтованого середовища AiiDA, де $\epsilon$ можливість запускати та керувати робочими процесами за допомогою спеціальних веб-програм та вебпереглядача. Вчителю надається низка додаткових сервісів: записи лекцій та інтерв'ю присвячених окремим аспектам та результатам новаторських досліджень у галузі молекулярного моделювання та моделювання матеріалів; збірка коротких навчальних курсів з обраних тем, проведених запрошеними лекторами. Використавши веб-додаток 3DBIONOTES-WS можливо здійснити демонстрацію дослідження вчених в онлайновому режимі та показати перебіг різних дослідження й отримані результати. Також, дослідницею запропоновано здійснювати добір засобів і сервісів за категоріями, що охоплюють весь спектр освітньої діяльності вчителя та використовувати інноваційні підходи та технології такі, як сервіси хмари відкритої науки та системи комп'ютерного моделювання.

До прикладу, опишемо позитивний досвід шведської організації «VA (Public\&Science)» щодо впровадження інструментів відкритої науки для суспільства і шкільної освіти. VA (Public\&Science) - це шведська неприбуткова організація (заснована у 2002 р.). Членами VA $€ 90$ організацій (університети, органи влади, асоціацій та компаній). Організація VA бере участь у проектах із спільно з європейськими партнерами та установами та є членом ECSA (European Citizen Science Association), ECSITE (Європейська мережа наукових центрів та музеїв) та EUSEA (European Science Engagement Association). Ha сайті «VA (Public\&Science)» зазначено, що «Відкрита наука - це зробити дослідження більш доступним та прозорим для інших дослідників та широкого суспільства». VA організовує багато заходів та заходів, спрямованих на стимулювання діалогу між дослідниками та громадськістю новими способами. Це шведський національний координатор щорічного європейського наукового фестивалю «Європейська ніч дослідників». В рамках «Європейської ночі дослідників» VA також проводить Гранпрі дослідників, конкурс наукових комунікацій для дослідників та масові експерименти в школах, які залучають учнів до реальних досліджень. Діяльність включає також конференції, наукові кафе та вебінари для вчених. Сюди входить щорічний барометр VA щодо загального ставлення шведської громадськості до науки та дослідників (Яцишин, 2021).

Організація VA бере активну участь у проектах, що сприяють впровадженню парадигми відкритої науки, а саме: «Європейська ніч дослідників» - проводиться щорічний науковий проект в рамках фестивалю науки ForskarFredag, за яким громадськість та учнів зі шкіл по всій Швеції запрошуються взяти участь у реальних дослідженнях; ЄС - Громадянин. Наука розробка європейської платформи для громадянської науки; ARCS - наука про громадян для всіх - розробка шведського вебпорталу для науки про громадян; Відкрита наука ORION - зробити дослідження в галузі наук про життя та біомедицину більш відкритими та включити більше соціальних перспектив у процес дослідження; Iнструменти RRI - за цим проектом було розроблено набір інструментів для підтримки відповідальних досліджень та інновацій; SciShops; Відкриті наукові семінари семінари з відкритої науки для університетів Швеції (Яцишин, 2021).

У роботі (Мар'єнко\&Шишкіна, 2020) розглянуто сервіс відкритого доступу arXiv, описано основи роботи 3 даним сервісом та особливості його використання для освітніх цілей. Сервіси спільної роботи над навчальними проектами теж можна вважати сервісами відкритої науки, оскільки більшість з них мають інструментарій для подальшого, публічного оприлюднення отриманих результатів. Також, наведено огляд месенджера Discord (в якому $\epsilon$ інструментарій задля 
створення відкритих спільнот (серверів) з метою подальшого приєднання будь-якого користувача), що останнім часом претендує на використання в хмаро орієнтованих системах, містить інструменти, які є хмарними та легко інтегрується 3 іншими сервісами завдяки відкритому коду.

Погоджуємося з тим, що «... багато відкритих наукових інструментів можуть покращити взаємозв'язки між дослідниками та вчителями, щоб викрити всі аспекти дослідницького процесу та полегшити впровадження практичних розробок в галузі освіти та педагогіки». Співпраця, можливо призведе до того, що новий програмний продукт створюватиметься шляхом обміну ідеями, щоб збалансувати потреби різних секторів та установ (навчальних та наукових). Поступове вдосконалення існуючих методик та методичних систем призведе до якісної зміни навчального процесу та професійного розвитку вчителів, що в свою чергу модернізує в шкільній практиці засоби та методи (Мар'єнко, 2021).

Проте існують соціокультурні, технічні та інституційні проблеми сприйняття відкритої науки, включаючи практичні підходи для подолання цих перешкод у програмах підготовки та күрсів підвищення кваліфікації педагогічних працівників (Мар'єнко, 2021).

У дослідженні (Мар'єнко, 2020) наголошено, що розглядаючи різні хмаро орієнтовані системи з точки зору відкритої науки, не всі вони відповідають основним принципам відкритої науки. Це мають бути хмарні сервіси, що розміщені на одній платформі та $\epsilon$ загальнодоступними, безкоштовними у використанні і містити контент, що $є$ відкритим для інших користувачів. Попри це, попередня реєстрація в хмаро орієнтованій системі не обов'язкова.

Завдяки ширшому залученню у процес наукових досліджень засобів і сервісів науково-освітніх мереж, зокрема хмаро орієнтованих, а також різних типів корпоративних хмарних сервісів вдається досягти позитивних змін у здійсненні цієі діяльності, поліпшенні ї̈ якісних і кількісних показників, застосуванні нових форм і моделей ії організації, що позитивно впливає як на результати навчання, так і на розвиток наукових досліджень, поліпшення рівня їх організації, підвищення ефективності (Шишкіна\&Попель, 2019).

Проаналізуємо детальніше основні напрями застосування хмаро орієнтованих технологій відкритої науки для професійного розвитку вчителів. У публікації (Рябова\&Єльникова, 2020) визначено чотири блоки навичок успішної професійної діяльності: 1) методи мислення (критичне мислення, креативність, проектний тип мислення, самостійне ухвалення рішень); 2) засоби праці (вільне володіння цифровими технологіями); 3) методи роботи (колаборативність та креативність); 4) блок навичок, що потрібні для успішної життєіяльності (професійна діяльність, громадянська позиція, особиста й соціальна відповідальність). 3 метою забезпечення розвитку цифрових навичок потребують модернізації змістові складові освітніх програм закладу освіти на цифровій проектноорієнтованій основі, що сприятиме кращому формуванню у фахівців м'яких навичок. Саме такий підхід забезпечить фахівцям, які завершать відповідний курс підвищення кваліфікації, спроможність отримання нових компетенцій з одночасним набуттям необхідних компетентностей (зокрема, цифрових) для ефективного виконання власних посадових обов'язків (Рябова\&Єльникова, 2020).

Для часткового вирішення описаних вище проблем щодо підвищення кваліфікації педагогічних працівників в умовах цифрової трансформації $€$ створено низку електронних освітніх курсів, що спрямовані на формування навичок «Hard skills i Soft skills так i Digitalskills». До прикладу, це курс «Управління закладом освіти як проєктноорієнтованою організацією», що спрямований на формування професійної компетентності управлінця закладу освіти. «Опановуючи зміст курсу, слухачі набувають уміння використовувати цифрові технології в професійній діяльності для вирішення питань надання якісних освітніх послуг закладом освіти. Це і проведення заходів (наприклад, навчальних занять, нарад, консультацій тощо) цифровими засобами, це і створення е-опитування (проведення голосування) визначення результативності навчання або стану виконання рішень за допомогою електронних таблиць та форм та ін.» (Рябова\&Єльникова, 2020).

Наразі, щоб переорієнтувати акцент від загальноприйнятого підходу до подальшого вдосконалення освіти, результати навчання можуть виступати засобом для вимірювання навчальної здатності учнів. Вчителі природничоматематичних предметів, що в подальшому будуть працювати в наукових ліцеях, мають орієнтуватись на самостійнопізнавальну діяльність ліцеїстів, оскільки ця діяльність відмінна від самостійної роботи. Самостійно-пізнавальна діяльність можлива не лише на занятті, але й дистанційно та може бути зорієнтована на самостійну підготовку до наступного заняття. Тому, в хмаро орієнтованій системі слід передбачити використання як окремих форм роботи: групових, індивідуальних, фронтальних, так і їх поєднання. Зрозуміло, що використання подібної системи призведе до зміни мети та змісту традиційного навчання (Мар'єнко, 2020).

Під час створення хмаро орієнтованої системи підготовки вчителів природничо-математичних предметів до роботи в науковому ліцеї варто враховувати такі ї̈ складники: по-перше - основу для застосувань знань з математики, техніки, інформатичних та гуманітарних наук, сучасних інструментів для успішного проектування, розробки та обслуговування комп'ютерних систем та динамічних процесів для досягнення педагогічних завдань вчителів та навчальних для учнів; подруге - спеціальний інструментарій як результат впливу технологій на суспільство, що допоможе з пошуком розв'язку сучасних, педагогічних проблем вчителів природничо-математичних предметів. Даний інструментарій має задовольняти потребу вчителів у навчанні протягом усього життя; по-третє - застосування хмарних сервісів допоможе вчителям брати дистанційну участь у командно-орієнтованих, відкритих заходах, які готують їх до роботи в інтегрованому цифровому середовищі; по-четверте - сприяння у розвитку педагогічної кар'єри вчителів, науково-дослідних розробках та привнесення практичної цінності наукових досліджень (як вчителів так і ліцеїстів). Тому, вчителям варто навчитися використанню розподілених обчислень та хмарних сервісів, щоб успішно підготуватись до роботи в наукових ліцеях (Мар'єнко, 2020).

У роботі (Вакалюк\&Мар'єнко, 2021) описано структуру дистанційного курсу «Хмарні сервіси відкритої науки для освітян», визначено його завдання, знання і вміння, які опановує учасник курсу по його успішному завершенню. У результаті вивчення даного дистанційного курсу учасник повинен: 1) знати (означення понять: відкрита наука, сервіс, хмарний сервіс, система; основні переваги використання хмарних сервісів; етапи наукового дослідження; спеціалізовані хмарні сервіси (як засіб впровадження відкритої науки) та їх різновиди; сервіси спільного опрацювання даних; сервіси спільної роботи над навчальними проєктами; сервіси відеоконференцій як сервіси організації спільної роботи; структуру хмари відкритої науки та класифікацію їі сервісів; етапи створення проєкту в хмарі відкритої науки; 2) уміти: аналізувати, оцінювати та обирати IKT 
для кожного етапу дослідження; використовувати сервіси відкритого доступу до наукових матеріалів та здійснювати пошук наукових публікацій; володіти основами роботи зі спеціалізованим хмарним сервісом; застосовувати сервіси відеоконференцій для організації спільної роботи; розробляти власний проєкт з використанням інструментарію хмари відкритої науки; додавати окремі сервіси до проєкту хмари відкритої науки. Також, у публікації [8] представлено процентний розподіл використання спеціалізованих хмарних сервісів учителями в залежності від типу уроків. 3 метою з'ясування стану сформованості компетентностей відкритої науки та оцінювання ефективності використання хмаро орієнтованої методичної системи підготовки вчителів природничо-математичних предметів до роботи в науковому ліцеї, виконувались констатувальні зрізи наступних складників: навички та досвід роботи у власній дисциплінарній спільноті та поза нею; навички та досвід щодо даних досліджень управління, аналізу/використання/повторного використання, розповсюдження. Зроблено висновок, що застосування хмаро орієнтованої методичної системи підготовки вчителів природничо-математичних предметів до роботи в науковому ліцеї сприяло підвищенню окремих компонентів компетентностей відкритої науки в освітян [8]. Для проходження даного курсу і отримання відповідного сертифікату можливо звернутися до його розробників і реалізаторів, а саме це Інститут інформаційних технологій і засобів навчання НАПН України та Державний університет «Житомирська політехніка».

Отже, на підставі аналізу наукової літератури (Вакалюк\&Мар'єнко, 2021; Литвинова, 2021; Мар'єнко,2020; Носенко\&Сухіх, 2020; Шишкіна\&Попель, 2019) та власного досвіду (Коваленко\&Литвинова\&Мар'єнко\&Шишкіна, 2020) розглянуто особливості застосування хмаро орієнтованих сервісів відкритої науки і зроблено візуалізацію основних напрямів застосування даних сервісів педагогічними працівниками (рис.1).

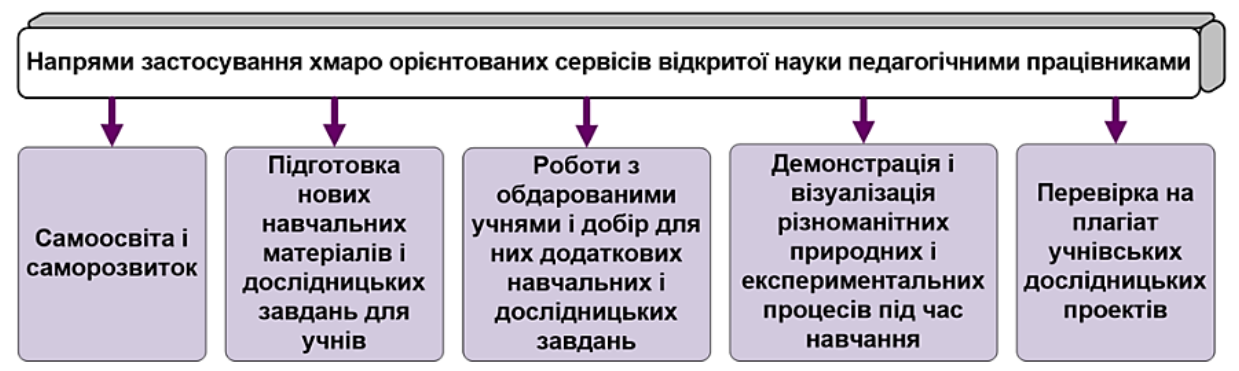

Рис. 1. Напрями застосування хмаро орієнтованих сервісів відкритої науки педагогічними працівниками

\section{ВИСНОВКИ ТА ПЕРСПЕКТИВИ ПОДАЛЬШОГО ДОСЛІДЖЕННЯ}

Проведене дослідження дає підстави зробити висновок, щодо важливості застосування принципів та інструментів відкритої освіти і науки для підвищення кваліфікації педагогічних працівників, адже в умовах глобальної цифровізації та карантинних обмежень викликаних хворобою COVID-19 саме на них покладена важливе суспільне завдання - не переривати освітній процес у закладах загальної середньої освіти, адже діти мають отримувати знання і здобувати освіту не зважаючи на суспільні обставини. Здійснивши аналіз наукових джерел та практичного досвіду було зроблено кілька узагальнень та підготовлено рекомендації щодо напрямів застосування хмаро орієнтованих сервісів відкритої науки педагогічними працівниками:

1. Для самоосвіти і саморозвитку педагогічних працівників (оскільки їх застосування забезпечує відкритий доступ до результатів наукових досліджень, сприяють пришвидшенню виконання досліджень та обміну досвідом, допомагають в реалізації спільних ініціатив, наукової комунікації і міжнародній співпраці та ін.)

2. Для підготовки нових навчальних матеріалів і дослідницьких завдань для учнів (їх застосування забезпечує осучаснення навчальних матеріалів і дослідницьких завдань та ознайомлення і актуальними науковими дослідженнями та їх результатами, що проводяться в усьому світі).

3. Для роботи з обдарованими дітьми і добір для них додаткових навчальних і дослідницьких завдань. 3 метою підготовки учнів для участі в різних олімпіадах і змаганнях.

4. Для демонстрації і візуалізації різноманітних природніх і експериментальних процесів під час освітнього процесу (показ таких відео і фото сприяє актуалізації та кращому засвоєнню навчального матеріалу).

5. Для перевірки на плагіат учнівських дослідницьких проектів.

Подальшого дослідження потребує детальний аналіз сервісів та інструментів відкритої освіти з метою застосування їх для самоосвіти педагогічних працівників.

\section{Список використаних джерел}

1. Beck M. W.et al. 2020. The importance of open science for biological assessment of aquatic environments. PeerJ. 2020. 8:e9539. DOI : 10.7717/peerj.9539.

2. Budroni P., Claude-Burgelman J., Schouppe M. Architectures of Knowledge: The European Open Science Cloud. ABI Technik, 2019. 39, 130-141.

3. EOSC Portal - A gateway to information and resources in EOSC. URL: https://eosc-portal.eu/.

4. European Commission / Shaping Europe's digital future. Open Science. URL: https://ec.europa.eu/digital-singlemarket/en/news/open-innovation-open-science-open-world-vision-europe.

5. Heck T., Peters I., Mazarakis A., Scherpc A., Blümel I. Open Science Practices in Higher Education : Discussion of Survey Results from Research and Teaching Staff in Germany. Education for Information. 2020. No. 36. P. 301-323. DOI: 10.3233/EFI-190272.

6. Shaping Europe's digital future. Open Science. URL: https://ec.europa.eu/digital-single-market/en/news/open-innovation-openscience-open-world-vision-europe. 
7. Биков В.Ю. Цифрова трансформація суспільства і розвиток комп'ютерно-технологічної платформи освіти і науки України. Матеріали метод семінару НАПН України "Інформаційно-цифровий освітній простір України: трансформаційні процеси і перспективи розвитку». 4 квітня 2019 р. К., 2019. С. 20-26.

8. Вакалюк Т.А., Мар'єнко М.В. Досвід використання хмаро орієнтованих систем відкритої науки в процесі навчання і професійного розвитку вчителів природничо-математичних предметів. Інформаційні технології і засоби навчання, 2021, №1(81). C.340-355. DOI: 10.33407/itlt.v81i1.4225.

9. Василенко А.Ю. Розвиток та реалізація політики відкритої науки в державах ЄС: приклад Франції. Державне управління: теорія та практика. №1. 2019. С. 71-77.

10. Коваленко В., Литвинова С., Мар'єнко М., Шишкіна М. Хмаро орієнтовані системи відкритої науки у навчанні і професійному розвитку вчителів: зміст основних понять дослідження. Фізико-математична освіта. 2020. Вип. 3(25). Частина 2. С. 67-74.

11. Корсікова К.Г. Самоосвіта сучасного вчителя як безперервний процес удосконалення педагогічної майстерності. Технології, інструменти та стратегії реалізації наукових досліджень. 20 березня 2020 р. С. 97-99.

12. Крива М., Пилипець С. Реалізація професійної самоосвіти вчителя початкових класів у сучасному освітньому інформаційно-комунікаційному просторі. Молодь і ринок. 2018. №10(165). DOI: https://doi.org/10.24919/23084634.2018.142322.

13. Литвинова С.Г. Засоби і сервіси хмаро орієнтованих систем відкритої науки для професійного розвитку вчителів ліцеїв. Науковий вісник ужгородського університету. серія: «Педагогіка. Соціальна робота». 2021. Вип. 1 (48). С. 225-230.

14. Лупаренко Л.А., Мар'єнко М.В. Носенко Ю.Г., Сухіх А.С., Шишкіна М.П. Концептуальний апарат дослідження: хмаро орієнтовані системи відкритої науки в навчанні і професійному розвитку вчителів. Вип. 29. Т. 2. 2020. С. 179-182.

15. Мар'єнко М. В. Хмаро орієнтовані системи відкритої науки у навчанні і професійному розвитку вчителів як наукова проблема. Житомирська політехніка. 2020. С. 138-139.

16. Мар'єнко М.В. Методика використання хмаро орієнтованих систем відкритої науки у процесі навчання і професійного розвитку вчителів. Фізико-математична освіта. 2021. Випуск 3(29). С. 99-104.

17. Мар'єнко М.В. Принципи, методи і підходи до формування хмаро орієнтованих систем відкритої науки у процесі навчання і професійного розвитку вчителів. Фізико-математична освіта. 2021. Випуск 1(27). С. 62-66.

18. Мар'єнко М.В. Психолого-педагогічні особливості формування хмаро орієнтованої системи підготовки вчителів природничо-математичних предметів до роботи в науковому ліцеї. Тези доповідей XI Міжнар. конф. «Іформаційнокомп'ютерні технології- 2020 (IКT-2020)", Житомир, 2020. С. 208-209.

19. Мар'єнко М.В., Носенко Ю.Г., Сухіх А.С. Розроблення проблеми використання хмаро орієнтованих систем відкритої науки у вітчизняному освітньому просторі. Освітній дискурс. 2020. № 10(27). DOI: 10.33930/ed.2019.5007.27(10)-7.

20. Мар'єнко М.В., Шишкіна М.П. Платформа відкритої науки та застосування ї компонентів в освітньому процесі. Інформаційні технології в освіті. 2020. 4(45).

21. Носенко Ю.Г., Сухіх А.С. Відкрита наука в контексті побудови суспільства знань і цифрових перетворень європейського простору. Фізико-математична освіта. 2020. Випуск 4(26). С. 85-92.

22. Рябова 3.В., Єльникова Г.В. Професійне зростання педагогів в умовах цифрової освіти. Інформаційні технології $і$ засоби навчання. 2020, Том 80, №6. C.369-385. DOI: 10.33407/itlt.v80i6.4202.

23. Шишкіна М., Попель М. Хмарні сервіси відкритої науки в освітньо-науковому середовищі університету / VII Міжнар. наук.практ. конф. "Глобальні та регіональні проблеми інформатизації в суспільстві і природокористуванні '2019", 15-16 травня 2019 р., НУБіп України, Київ. С. 232-234.

24. Шишкіна М.П. Організація навчального й наукового співробітництва у віртуальних системах відкритої науки у закладах вищої освіти. Освіта дорослих: теорія, досвід, перспективи. 2020. Вип. 2 (18). С. 122-130.

25. Яцишин А.В. Теоретико-методичні основи використання цифрових відкритих систем у підготовці аспірантів і докторантів з наук про освіту: дисертація ... д.пед.н.; 13.00.10 - Інформаційно-комунікаційні технології в освіті / Інститут інформаційних технологій і засобів навчання НАПН України. К., 2021. 636 с.

\section{References}

1. Beck M. W.et al. (2020). The importance of open science for biological assessment of aquatic environments. PeerJ. 2020. 8:e9539. DOI : 10.7717/peerj.9539. [in English]

2. Budroni P., Claude-Burgelman J. \& Schouppe M. (2019) Architectures of Knowledge: The European Open Science Cloud. ABI Technik,. 39, 130-141. [in English]

3. EOSC Portal - A gateway to information and resources in EOSC. URL: https://eosc-portal.eu/. [in English]

4. European Commission / Shaping Europe's digital future. Open Science. URL: https://ec.europa.eu/digital-singlemarket/en/news/open-innovation-open-science-open-world-vision-europe. [in English]

5. Heck T., Peters I., Mazarakis A., Scherpc A. \& Blümel I. (2020) Open Science Practices in Higher Education : Discussion of Survey Results from Research and Teaching Staff in Germany. Education for Information. No. 36. P. 301-323. DOI: 10.3233/EFI-190272. [in English]

6. Shaping Europe's digital future. Open Science. URL: https://ec.europa.eu/digital-single-market/en/news/open-innovation-openscience-open-world-vision-europe. [in English]

7. Bykov, V. Yu. (2019) Tsyfrova transformatsiia suspilstva i rozvytok kompiuterno-tekhnolohichnoi platformy osvity i nauky Ukrainy [Digital transformation of society and development of computer-technological platform of education and science of Ukraine]. Materials of the method of the seminar of the National Academy of Educational Sciences of Ukraine "Information and digital educational space of Ukraine: transformation processes and prospects of development". April 4, 2019-K., p.20-26. [in Ukrainian]

8. Vakalyuk TA., Marienko M. (2021) Dosvid vykorystannia khmaro oriientovanykh system vidkrytoi nauky v protsesi navchannia $\mathrm{i}$ profesiinoho rozvytku vchyteliv pryrodnycho-matematychnykh predmetiv [Experience of using cloud-oriented systems of open 
science in the process of teaching and professional development of teachers of natural sciences and mathematics]. Information Technologies and Learning Tools, №1(81). p.340-355. DOI: 10.33407/itlt.v81i1.4225. [in Ukrainian]

9. Vasilenko A.Yu. (2019) Rozvytok ta realizatsiia polityky vidkrytoi nauky v derzhavakh YeS: pryklad Frantsii [Development and implementation of open science policy in the EU: the example of France] Public administration: theory and practice. №1. p.7177. [in Ukrainian]

10. Kovalenko V., Litvinova S., Marienko M. \& Shishkina M. (2020) Khmaro oriientovani systemy vidkrytoi nauky u navchanni i profesiinomu rozvytku vchyteliv: zmist osnovnykh poniat doslidzhennia [Cloud-oriented systems of open science in teaching and professional development of teachers: the content of the basic concepts of the study]. Physical and Mathematical Education. Issue. 3(25). p. 67-74. [in Ukrainian]

11. Korsikova KG (2020) Samoosvita suchasnoho vchytelia yak bezperervnyi protses udoskonalennia pedahohichnoi maisternosti. [Self-education of a modern teacher as a continuous process of improving pedagogical skills]. Technologies, tools and strategies for research. March 20, 2020. p.97-99. [in Ukrainian]

12. Kryva M. \& Pylypets S. (2018) Realizatsiia profesiinoi samoosvity vchytelia pochatkovykh klasiv u suchasnomu osvitnomu informatsiino-komunikatsiinomu prostori [Implementation of professional self-education of primary school teachers in the modern educational information and communication space]. Youth and the market. №10(165). DOI: https://doi.org/10.24919/2308-4634.2018.142322. [in Ukrainian]

13. Litvinova S. (2021) Zasoby i servisy khmaro oriientovanykh system vidkrytoi nauky dlia profesiinoho rozvytku vchyteliv litseiv [Tools and services of cloud-based open science systems for professional development of lyceum teachers]. Scientific Bulletin of Uzhhorod University. series: "Pedagogy. Social work". Issue. 1 (48). p. 225-230. [in Ukrainian]

14. Luparenko L.A., Marienko M., Nosenko Yu.G., Sukhikh A.S. \& Shishkina M.P. (2020) Kontseptualnyi aparat doslidzhennia: khmaro oriientovani systemy vidkrytoi nauky v navchanni i profesiinomu rozvytku vchyteliv [Conceptual apparatus of research: cloudoriented systems of open science in teaching and professional development of teachers]. Issue. 29. T.2. p.179-182.

15. Marienko M. (2020) Khmaro oriientovani systemy vidkrytoi nauky u navchanni i profesiinomu rozvytku vchyteliv yak naukova problema [Cloud-oriented systems of open science in teaching and professional development of teachers as a scientific problem]. Zhytomyr Polytechnic. p. 138-139. [in Ukrainian]

16. Marienko M. (2021) Metodyka vykorystannia khmaro oriientovanykh system vidkrytoi nauky u protsesi navchannia i profesiinoho rozvytku vchyteliv [Methods of using cloud-based systems of open science in the process of teaching and professional development of teachers]. Physical and Mathematical Education. Issue 3(29). p. 99-104. [in Ukrainian]

17. Marienko M. (2021) Pryntsypy, metody i pidkhody do formuvannia khmaro oriientovanykh system vidkrytoi nauky u protsesi navchannia i profesiinoho rozvytku vchyteliv [The principles, methods and approaches to the formation of cloud-based systems of open science in the process of teaching and professional development of teachers]. Physical and Mathematical Education. Issue 1(27). p. 62-66. [in Ukrainian].

18. Marienko M. (2020) Psykholoho-pedahohichni osoblyvosti formuvannia khmaro oriientovanoi systemy pidhotovky vchyteliv pryrodnycho-matematychnykh predmetiv do roboty v naukovomu litsei [Psychological and pedagogical features of the formation of a cloud-based system of training teachers of natural and mathematical subjects to work in a scientific lyceum]. Abstracts of the XI International. conf. "Information and Computer Technologies - 2020 (ICT-2020)", Zhytomyr, 2020. p. 208-209. [in Ukrainian]

19. Marienko M., Nosenko Yu.G. \& Sukhikh A.S. (2020) Rozroblennia problemy vykorystannia khmaro oriientovanykh system vidkrytoi nauky u vitchyznianomu osvitnomu prostori [Development of the problem of using cloud-oriented systems of open science in the domestic educational space]. Educational discourse. № 10(27). DOI: 10.33930/ed.2019.5007.27(10)-7. [in Ukrainian]

20. Marienko M. \& Shishkina M.P. (2020) Platforma vidkrytoi nauky ta zastosuvannia yii komponentiv v osvitnomu protsesi [Open science platform and application of its components in the educational process]. Information technology in education. 2020. 4(45). [in Ukrainian]

21. Nosenko Yu.G. \& Sukhikh A.S. (2020) Vidkryta nauka v konteksti pobudovy suspilstva znan i tsyfrovykh peretvoren yevropeiskoho prostoru [Open science in the context of building a knowledge society and digital transformations of the European space]. Physical and Mathematical Education. Issue 4(26). p. 85-92. [in Ukrainian]

22. Ryabova ZV \& Yelnikov GV. (2020) Profesiine zrostannia pedahohiv v umovakh tsyfrovoi osvity [Professional growth of teachers in digital education]. Information Technologies and Learning Tools. Issue №6(80). C.369-385. DOI: 10.33407/itlt.v80i6.4202. [in Ukrainian]

23. Shishkina M.P. \& Popel M. (2019) Khmarni servisy vidkrytoi nauky v osvitno-naukovomu seredovyshchi universytetu [Cloud services of open science in the educational and scientific environment of the university] VII International. scientific-practical conf. "Global and regional problems of informatization in society and nature management '2019", May 15-16, 2019, NULES of Ukraine, Kyiv. p. 232-234. [in Ukrainian]

24. Shishkina M.P. (2020) Orhanizatsiia navchalnoho y naukovoho spivrobitnytstva u virtualnykh systemakh vidkrytoi nauky u zakladakh vyshchoi osvity [Organization of educational and scientific cooperation in virtual systems of open science in higher education institutions]. Adult education: theory, experience, prospects. Issue. 2 (18). p. 122-130. [in Ukrainian]

25. latsyshyn A. (2021) Teoretyko-metodychni osnovy vykorystannia tsyfrovykh vidkrytykh system u pidhotovtsi aspirantiv $i$ doktorantiv z nauk pro osvitu [Theoretical and methodical bases of digital open systems use in preparation of postgraduate and doctoral students in educational sciences] dissertation... doctor of pedagogical sciences; 13.00 .10 - Information and communication technologies in education / Institute of Information Technologies and Learning Tools of NAES of Ukraine, Kyiv, 2021. 636 p. [in Ukrainian] 


\section{APPLICATION OF CLOUD ORIENTED OPEN SCIENCE SERVICES FOR PROFESSIONAL DEVELOPMENT OF TEACHERS Valentyna Kovalenko}

Institute of Information Technologies and Learning Tools of NAES of Ukraine, Ukraine

Abstract. The article analyzes the features of the use of cloud-based open science services for the professional development of teachers. The importance of applying the principles and tools of open education and science to improve the skills of teachers, especially in the context of global digitalization. Recommendations on the areas of application of cloud-based open science services by teachers have been prepared: for self-education and self-development of teachers; to prepare new teaching materials and research tasks for students; to work with gifted children and select additional educational and research tasks for them; to demonstrate and visualize various natural and experimental processes during the educational process; to check for plagiarism of student research projects.

Formulation of the problem. For this study, it is important to analyze the features of the use of cloud-based open science services for professional development of teachers. Therefore, we will analyze the process of training future teachers, examples of the use of cloud-based open science services in the practice of ZSSO and professional development of teachers with the use of open science services.

Materials and methods. To achieve the goal of the study, theoretical methods were used: analysis, systematization, generalization of scientific sources, analysis of scientific publications of domestic and foreign scientists. The research was performed within the project "Cloudoriented systems of open science in teaching and professional development of teachers" (registration number 2020.02 /0310), which is implemented with grant support from the National Research Foundation of Ukraine.

Results. The study analyzes the features of the use of cloud-based open science services for professional development of teachers. The conclusion is made about the importance of applying the principles and tools of open education and science to improve the skills of teachers, especially in the context of global digitalization. Recommendations on the areas of application of cloud-based open science services by teachers have been prepared: for self-education and self-development of teachers; to prepare new teaching materials and research tasks for students; to work with gifted children and select additional educational and research tasks for them; to demonstrate and visualize various natural and experimental processes during the educational process; to check for plagiarism of student research projects.

Conclusions. The study gives grounds to conclude that the importance of applying the principles and tools of open education and science to improve the skills of teachers, because in the context of global digitalization and quarantine restrictions caused by COVID-19 they have an important social task - not to interrupt the educational process in institutions general secondary education, because children must receive knowledge and receive education regardless of social circumstances.

Key words: open science, tools of open science, digital technologies, teachers, professional development. 